\title{
A POTENTIAL BIOLOGICAL CONTROL AGENT FOR GREENHOUSE THRIPS
}

\author{
K.J. FROUD ${ }^{1}$, P.S. STEVENS ${ }^{2}$ and D.R. COWLEY ${ }^{1}$ \\ ${ }^{1}$ School of Biological Sciences, University of Auckland, \\ Private Bag 92019, Auckland \\ ${ }^{2}$ HortResearch, Private Bag 92 169, Auckland
}

\begin{abstract}
Greenhouse thrips (Heliothrips haemorrhoidalis)(Thysanoptera : Terebrantia) damage citrus, avocados and ornamental plants in New Zealand. A potential biological control agent, Thripobius semiluteus, (Hymenoptera : Eulophidae) has been imported into quarantine from California. This parasitoid attacks first instar and to a lesser extent second instar H. haemorrhoidalis larvae. Some aspects of the host/ parasitoid relationship are described. Host records from India, Australia, Africa, North and South America have demonstrated that $T$. semiluteus only parasitises thrips within the subfamily Panchaetothripinae. Sigmothrips aotearoana is the only endemic species of Panchaetothripinae in New Zealand and has been collected from native vegetation. Laboratory experiments have shown that $T$. semiluteus can parasitise and complete development inS. aotearoana. However, when T. semiluteus is offered a choice between $S$. aotearoana and greenhouse thrips, significantly more greenhouse thrips are parasitised and significantly more parasitoids successfully complete development on greenhouse thrips than on $S$. aotearoana.
\end{abstract}

Keywords: Biological control, quarantine testing, parasitoids, thrips

\section{INTRODUCTION}

Greenhouse thrips (Heliothrips haemorrhoidalis Bouché), which were first recorded in New Zealand in the 1930's, are abundant in the North Island and are found as far south as Nelson in the South Island (Mound and Walker 1982). They are a serious pest on citrus, avocados and a wide range of ornamentals. Spiller and Wise (1982) recorded more than 30 host plants in New Zealand. Greenhouse thrips cause damage by feeding on the mesophyll tissue of fruit and leaves. Fresh damage on citrus fruit appears as silvered areas with faecal spots and older damage shows as brown scaling, which can drop off leaving smooth silver scars (Holt 1989). Damage to avocado fruit appears as bronzed areas with faecal spots.

There are no records of any parasitoids attacking greenhouse thrips in New Zealand (Mound and Walker 1982; D. Steven unpublished data). Research carried out in Australia (Beattie and Jiang 1990) and the USA (McMurtry 1988, 1992) indicates that the best candidate for biological control of greenhouse thrips is the eulophid parasitoid Thripobius semiluteus Boucek, which has also been recorded as a parasitoid of greenhouse thrips in Africa, India (Boucek 1976) and Brazil (LaSalle and McMurtry 1989). The parasitoidT. semiluteus was imported from FAR Inc. insectaries in Corona, California, U.S.A. and placed into the HortResearch insect quarantine facility at Mt. Albert in April 1995.

Host preference experiments were carried out in quarantine to determine whether $T$. semiluteus was likely to have any harmful impact on non-target thrips.

Records show $T$. semiluteus only parasitises Thripidae in the subfamily Panchaetothripinae (LaSalle and McMurtry 1989). It parasitises thrips larvae in the first and sometimes the second instar stage and emerges from the pupal stages of the 
thrips. None of the recorded hosts (except the greenhouse thrips) are known to be present in New Zealand. There are four other species of Panchaetothripinae in New Zealand. Three of the species, the banana-silvering thrips (Hercinothrips bicinctus Bagnall), the banded greenhouse thrips (Hercinothrips femoralis Bagnall) and the palm thrips (Parthenothrips dracaenae Heeger) are either exotic pests or potential pests (Mound and Walker 1982). However, the fourth speciesSigmothrips aotearoana Ward is endemic to New Zealand. There is little known of S. aotearoana, other than that it lives on native seedlings mostly ofCoprosmaspp. andGeniostoma ligustrifolium, and appears to pupate in the soil, as opposed to greenhouse thrips which pupates on the host plant (Mound and Walker 1982).

This paper compares the host preference of the exotic parasitoid T. semiluteus, for the native thrips species $S$. aotearoana compared with greenhouse thrips.

\section{METHODS}

Insects for the experiments were provided from colonies of greenhouse thrips and $S$. aotearoana, reared on lemons and Coprosma robusta respectively. Host preference tests were carried out in 3.5 litre clear plastic canisters with fine mesh ventilation. All experiments were carried out at a constant temperature of $23^{\circ} \mathrm{C}$, relative humidity range of 65-75 \% and a photoperiod of L:D 16:8.

$T$. semiluteus was provided with either a choice between $S$. aotearoana and greenhouse thrips, or $S$. aotearoana or greenhouse thrips alone. Five inexperienced female parasitoids of a known age (24-48 hours after emergence) were introduced into the plastic canisters for both the choice and no-choice tests for a period of $24 \mathrm{hrs}$. Each canister also contained a known number of potential thrips hosts. Each comparison was replicated five times.

\section{No-choice tests}

T. semiluteus were placed (using a paintbrush) into the canisters, with either 50 first instar S. aotearoana larvae on a C. robusta seedling (kept alive in a small covered flask of water) or 50 first instar greenhouse thrips larvae on an unripe lemon. Adult parasitoids were removed after $24 \mathrm{~h}$, leaving the thrips larvae in the canister to complete development. After two weeks, damp vermiculite was placed into the cage with $S$. aotearoana to allow pupation and subsequent parasitoid emergence.

\section{Choice tests}

The five $T$. semiluteus were provided with 50 first instar larvae of both $S$. aotearoana and of greenhouse thrips. The $S$. aotearoana were provided on a C. robusta seedling and the greenhouse thrips were placed on an unripe lemon. After 24 hours, the five parasitoids were removed and the seedling and lemon were placed into separate containers for development. Damp vermiculite was provided for $S$. aotearoana after two weeks.

\section{Assessment}

A check was made of all experiments after 14-18 days for greenhouse thrips and 18-24 days for $S$. aotearoana. The number of adult thrips of each species and number of $T$. semiluteus pupae (black compared to the cream colouration of thrips pupae) were recorded. Another check was made after 20-25 days for greenhouse thrips and 25-35 days for $S$. aotearoana for numbers of emerged adult parasitoids. Statistical analyses for significant differences were performed using t-tests. Data were analysed using the computer programme SAS (SAS Institute Inc. 1985). Percentages were angular transformed before analysis, but untransformed data are presented.

\section{No-choice tests}

\section{RESULTS}

Almost all the greenhouse thrips larvae exposed to $T$. semiluteus were parasitised. By comparison, very few $S$. aotearoana larvae were parasitised (Table 1). The percentage of parasitoids completing development and emerging as adults from greenhouse thrips was very high and significantly higher than from S. aotearoana (Table 1). 
TABLE 1: Mean $\boldsymbol{H}$. haemorrhoidalis and $S$. aotearoana larval parasitism in no-choice tests and percent emergence of adult parasitoids in each species $(\mathbf{n}=5)$.

\begin{tabular}{lcc}
\hline Thrips species & $\begin{array}{c}\text { Number of parasitoid } \\
\text { pupae formed } \\
(\text { mean } \pm \text { SE })\end{array}$ & $\begin{array}{c}\text { Emergence of adult } \\
\text { parasitoids } \\
(\text { mean } \pm \text { SE })\end{array}$ \\
\hline H. haemorrhoidalis & $46.4 \pm 1.17 \mathrm{a}^{1}$ & $95.29 \pm 1.38 \mathrm{a}$ \\
S. aotearoana & $3.4 \pm 1.12 \mathrm{~b}$ & $52.68 \pm 12.72 \mathrm{~b}$ \\
\hline
\end{tabular}

${ }^{1}$ Numbers within a column with the same letter are not significantly different (t-test, $\mathrm{P}>0.05)$

\section{Choice tests}

When $T$. semiluteus was provided with a choice, significantly more greenhouse thrips were parasitised compared to $S$. aotearoana and significantly more parasitoids completed development on greenhouse thrips compared to $S$. aotearoana (Table 2).

TABLE 2: Mean $\boldsymbol{H}$. haemorrhoidalis and $S$. aotearoana larval parasitism in choice tests and percent emergence of adult parasitoids in each species $(\mathbf{n}=\mathbf{5})$.

\begin{tabular}{lcc}
\hline Thrips species & $\begin{array}{c}\text { Number of parasitoid } \\
\text { pupae formed } \\
\text { ( mean } \pm \mathrm{SE})\end{array}$ & $\begin{array}{c}\text { \% Emergence of adult } \\
\text { parasitoids } \\
(\text { mean } \pm \mathrm{SE})\end{array}$ \\
\hline H. haemorrhoidalis & $45.2 \pm 2.48 \mathrm{a}^{1}$ & $93.50 \pm 1.45 \mathrm{a}$ \\
S. aotearoana & $4.4 \pm 2.32 \mathrm{~b}$ & $36.79 \pm 12.10 \mathrm{~b}$ \\
\hline
\end{tabular}

${ }^{1}$ Numbers within a column with the same letter are not significantly different (t-test, $\mathrm{P}>0.05)$

In both choice and no-choice situations, the non-parasitised larval and pupal mortality of S. aotearoana was very high at $79.6 \%$ and $92 \%$ respectively, compared to very low rates for greenhouse thrips of $5.6 \%$ and $4 \%$ respectively. However death in $S$. aotearoana did not occur in the first $24 \mathrm{~h}$ and in most cases not until 14-20 days later in the late second instar and pupal stages.

\section{DISCUSSION}

This parasitoid has the potential to be a very effective biological control agent of greenhouse thrips. Results in California and Israel, where it has been introduced (1986 and 1991 respectively), indicate that $T$. semiluteus establishment is correlated with greenhouse thrips decline (McMurtry et al. 1991; Y. Izhar, Ministry of Agriculture, Israel, pers. comm.).

The laboratory experiments described in this paper have shown that $T$. semiluteus can successfully parasitise and complete development on the endemic thrips $S$. aotearoana. Although greenhouse thrips were found to be the preferred host, a few $S$. aotearoana were parasitised in both the choice and the no choice situation. The number of parasitised $S$. aotearoana was not affected by the presence or absence of the preferred host species greenhouse thrips, suggesting that T. semiluteus would not attack significant numbers of $S$. aotearoana in the field, even in the absence of greenhouse thrips. The few S. aotearoana which were parasitised, in both the choice and no choice situation could be indicative of imperfect host recognition (Michaud and Mackauer 1995). An analysis of the host location and host acceptance behaviour of T. semiluteus could help clarify this. 
The percentage of parasitoids developing through to adults on S. aotearoana is very low in comparison with greenhouse thrips, indicating again that $S$. aotearoana is not as suitable a host.

Laboratory host preference tests have many acknowledged weaknesses (Simmonds 1944). For example Sands (1993) states "insect enemies of arthropod pests, when confined in cages, can sometimes utilise hosts or prey not normally attacked in the field." The results from these experiments suggest that $S$. aotearoana will be occasionally attacked in the wild if T. semiluteus is introduced. However, greenhouse thrips and $S$. aotearoana have very distinct habitats, the former rarely occurring in the native bush where $S$. aotearoana is found. This habitat separation between the two thrips species should decrease the chances of $S$. aotearoana being parasitised by $T$. semiluteus. However, even if a low level of parasitism does occur in $S$. aotearoana, the potential benefits could outweigh this risk. Further research to investigate the effect $T$. semiluteus has on $S$. aotearoana in the laboratory will have to be carried out, particularly whether $T$. semiluteus contributed to the high pupal mortality of $S$. aotearoana in the trials, before any final decisions can be made about the introduction of T. semiluteus.

\section{ACKNOWLEDGEMENTS}

We would like to thank Cathy McKenna, John Charles and Max Suckling for editorial assistance and Chris Henry for supplying the lemons for the colonies.

\section{REFERENCES}

Beattie, G.A.C. and Jiang, L., 1990. Greenhouse thrips and its parasitoids in coastal New South Wales. Gen. App. Ento. 22: 21-24.

Boucek, Z., 1976. Taxonomic studies on some Eulophidae (Hym.) of economic interest, mainly from Africa. Entomophaga 21: 401-414.

Holt, V.A., 1989. Pest status and inter-relationships between three species of thrips, (Thysanoptera: Terebrantia) Heliothrips haemorrhoidalis, Megalurothrips kellyanus, and Thrips obscuratus, present on citrus in the Auckland area. Unpublished MSc Thesis, University of Auckland. 155pp.

LaSalle, J. and McMurtry, J.A., 1989. First record of Thripobius semiluteus (Hymenoptera : Eulophidae) from the New World.Proc. Entomol. Soc. Wash.91: 634.

McMurtry, J.A., 1988. Biological control on greenhouse thrips. Citrograph 73: 81-82.

McMurtry, J.A., 1992. The role of exotic natural enemies in the biological control of insect and mite pests of avocado in California. Proc. of Second World Avocado Congress: 247-252.

McMurtry, J.A., Johnson, H.G. and Newberger, S.J., 1991. Imported parasite of greenhouse thrips established on California avocado. California Agric. 45:31-32.

Michaud, J.P. and Mackauer, M., 1995. The use of visual cues in host evaluation by aphidiid wasps. II. Comparison between Ephedrus californicus, Monoctonus paulensis, and Praon pequodorum. Entomol. Exp. Appl. 74: 267-275.

Mound, L.A. and Walker, A.K., 1982. Terebrantia (Insecta: Thysanoptera). Fauna of New Zealand (1). Science and Information Division, D.S.I.R. Wellington, 120pp.

Sands, D.P.A., 1993. Effects of confinement on parasitoid-host interactions: interpretation and assessment for biological control of arthropod pests. Pp 196199.In: Pest Control and Sustainable Agriculture, S.A. Corey, D.J. Dall and W.M. Milne, (Eds.); CSIRO, Canberra, Australia.

Simmonds, F.J., 1944. The propagation of insect parasites on unnatural hosts. Bull. Ento. Res. 35: 219-226.

Spiller, D.M. and Wise, K.A., 1982. A Catalogue (1860-1960) of New Zealand Insects and their Host Plants. D.S.I.R. Bulletin 231, Science Information Division, D.S.I.R., Wellington, 260pp. 